\title{
EGFR NM_005228.3:c.2308_2309ins9
}

National Cancer Institute

\section{Source}

National Cancer Institute. EGFR NM 005228.3:C.2308 2309ins9. NCI Thesaurus. Code C98618.

An insertion of nine nucleotides, CCAGCGT GG, between position 2308 and 2309 of the coding sequence of the EGFR gene. 